\title{
Replacement of Inorganic Zinc with Various Organic Zinc Sources on Haematological Constituents, Antioxidant Status, Immune Response and Reproductive Efficiency in Rats
}

\author{
D. Nagalakshmi ${ }^{1}$, K. Sadasiva Rao $^{2}$, G. Aruna Kumari ${ }^{3}$, \\ S. Parashuramulu ${ }^{4}$ and K. Sridhar ${ }^{5^{*}}$ \\ ${ }^{1}$ College of Veterinary Science, Rajendranagar, Hyderabad, Telanagana -500 030, India \\ ${ }^{2}$ College of Veterinary Science, Gannavaram, Andhra Pradesh, India \\ ${ }^{3}$ Department of Veterinary Gynaecology and Obstetrics, College of Veterinary Science, \\ Rajendranagar, Hyderabad, Telanagana, India \\ ${ }^{4}$ Chalimeda feeds Pvt Ltd, Karimnagar, Telangana, India \\ ${ }^{5}$ Department of Animal Nutrition, College of Veterinary Science, Rajendranagar \\ Hyderabad, Telanagana -500 030, India \\ *Corresponding author
}

\section{A B S T R A C T}

The present study was undertaken on 60 adult female Sprague Dawley rats $(275 \pm 2.04 \mathrm{~g})$ for an experimental duration of 84 days to evaluate various organic sources of zinc on

\section{Keywords}

Folliculogenesis, Immunity, Organic zinc, Oxidative stress,

Progesterone.

Article Info

Accepted:

20 January 2017

Available Online:

10 February 2017 immunity, reproduction, oxidative defense mechanism in rats. The rats were randomly allotted to 5 dietary treatments (6 replicates in each) prepared by varying the source of $\mathrm{Zn}$ supplementation (12 ppm) either from inorganic ( $\mathrm{Zn}$ carbonate) or sources (Zn proteinate, $\mathrm{Zn}$ propionate, $\mathrm{Zn}$ amino acid complex and $\mathrm{Zn}$ methionine). Supplementation of organic zinc had no significant effect on performance, haematological and serum biochemical parameters, TBARS and protein carbonyls concentration in liver. The glutathione reductase activity $(\mathrm{P}<0.05)$ in haemolysate and reduced glutathione concentration in liver $(\mathrm{P}<0.01)$ was higher in organic $\mathrm{Zn}$ fed rats, while highest $(\mathrm{P}<0.01) \mathrm{RBC}$ catalase activity was noticed with $\mathrm{Zn}$ methionine supplementation. The humoral immune response against sheep $\mathrm{RBC}$ was increased $(\mathrm{P}<0.05)$ with organic $\mathrm{Zn}$ supplementation. The cell mediated immune response was higher $(\mathrm{P}<0.05)$ in $\mathrm{Zn}$ propionate group. The serum progesterone concentration was higher $(\mathrm{P}<0.05)$ in rats fed organic $\mathrm{Zn}$ sources. Organic $\mathrm{Zn}$ supplementation increased $(\mathrm{P}<0.05)$ the number of graafian follicles and corpus luteum. The study indicated that supplementing $12 \mathrm{ppm}$ of $\mathrm{Zn}$ from various organic sources had higher antioxidant enzyme activities, immune response and serum progesterone concentration with higher number of mature follicles in ovaries compared to inorganic.

\section{Introduction}

Zinc $(\mathrm{Zn})$ by being a component of more than 300 metalloenzymes influences the growth, immunity, antioxidant mechanism and reproductive performance of animals (Hafeez et al., 2013). In addition, previous experiments conducted at author's laboratory indicated improved immunity, reproduction and oxidative defense mechanism in rats fed 
diets containing $\mathrm{Zn}$ (Zinc carbonate) up to 36 ppm (Nagalakshmi et al., 2009, 2012, 2013 $\mathrm{a} \& \mathrm{~b})$. However, over supplementation of $\mathrm{Zn}$ may interfere with the absorption and availability of other minerals which are also essential for normal physiological activities of animals (Nitrayova et al., 2012; Sridhar et al., 2015a). Hence, to overcome this concept of organic minerals was established, in which $\mathrm{Zn}$ supplementation recommended or lower than the recommendations may sufficient for better immunity, antioxidant status and reproductive performance (Sridhar et al., 2016; Nagalakshmi et al., 2015a,b; 2016a,b). Even though this concept well established, there are conflicts among the researches on relative bioavailability/effectiveness among organic $\mathrm{Zn}$ sources, because the availability of mineral is mainly depend on the physicchemical bonding between ligand and mineral. Therefore, here authors made an attempt to evaluate the various organic sources ( $\mathrm{Zn}$ proteinate, $\mathrm{Zn}$ propionate, $\mathrm{Zn}$ amino acid complex and $\mathrm{Zn}$ methionine) of zinc on immunity, reproduction, oxidative defense mechanism in rats

\section{Materials and Methods}

A study was conducted on 60 adult female Sprague Dawley rats (SD) strain with an average body weight of $275 \pm 2.04 \mathrm{~g}$. The rats were housed in polypropylene cages in the Animal House of College of Veterinary Science, Hyderabad under hygienic conditions with controlled temperature (22$\left.23^{\circ} \mathrm{C}\right)$ and photoperiod $(12 \mathrm{~h} / \mathrm{d})$. The rearing and care of rats and procedures adopted were according to the guidelines of Institutional Animal Ethics Committee and permission has been taken from the same for experimentation. The approval number from ethics committee for this experiment was $\mathrm{I} / 2 / 11$ on dated 14.03.2011. The rats were provided with respective diet adlibitum and with free access to wholesome clean deionized water. Water was provided in polypropylene bottles having provision for nipples. The animals were randomly divided into 30 replicates with 2 rats per replicate and these 30 replicates in turn were randomly allotted to 5 dietary treatments varying in source of $\mathrm{Zn}$ so as to supply $12 \mathrm{ppm} \mathrm{Zn}$ as per NRC (1995) recommendation. The rats were fed with the respective diets for an experimental duration of 12 weeks. A basal diet (BD) based on AIN- 76A rodent diet for adult rats was formulated using purified ingredients (Table 1) to this $12 \mathrm{ppm} \mathrm{Zn} \mathrm{was}$ added from inorganic source ( $\mathrm{Zn}$ carbonate) and this served as control diet. The other 4 experimental diets were similar to control diet except the $\mathrm{ZnCO}_{3}$ was replaced with various organic $\mathrm{Zn}$ sources viz., zinc proteinate ( $\mathrm{Zn}$ prot), zinc propionate ( $\mathrm{Zn}$ prop), zinc amino acid complex ( $\mathrm{Zn} \mathrm{AA}$ ) and zinc methionine (Zn met) supplementing $12 \mathrm{ppm} \mathrm{Zn}$. During experimentation, weekly body weights and daily feed intake were recorded. At $50^{\text {th }} \mathrm{d}$, blood was collected by retro-orbital puncture to analyze the haematological and biochemical constituents. At $55^{\text {th }} \mathrm{d}$ of experiment, all rats were antigenically challenged with sheep RBC to assess the humoral immune response. The cell mediated immune response was assayed by footpad reaction method on $80^{\text {th }}$ day of the experiment. On $83^{\text {rd }} \mathrm{d}$ of the experiment, blood was collected to assess the antioxidant enzymes. After 12 weeks of feeding, rats were sacrificed and livers and ovaries were collected for antioxidant enzymes in liver and ovarian histology, respectively.

\section{Haematological constituents}

For haematology, blood was collected on $50^{\text {th }}$ $\mathrm{d}$ from all rats after overnight fasting in heparinized vacutainers. Haemoglobin $(\mathrm{Hb})$ content, red blood cell (RBC) and white blood cell (WBC) counts, mean corpuscular volume $(\mathrm{MCV})$, mean corpuscular hemoglobin 
$(\mathrm{MCH})$, mean corpuscular hemoglobin concentration (MCHC), lymphocyte and granulocyte percentage were determined by automatic blood analyser (Huma count, Med source Ozone biomedical Pvt. Ltd, India).

\section{Serum biochemical constituents}

After collecting blood in heparinized vacutainers, blood was also collected in serum vacutainers with no anticoagulant and then centrifuged at $3500 \mathrm{rpm}$ for 15 minutes. The serum was collected and stored at $20^{\circ} \mathrm{C}$ for analysis. The glucose was determined by $\mathrm{O}$ toludine method (Cooper and Mc Daniel, 1970) cholesterol by the method described by Wybenga and Pileggi's (1970). Serum total protein and albumin levels were estimated according to the methods described by Reinhold (1953) and Gustafsson (1956) respectively. The globulin was determined as the difference between total protein and albumin concentration in the serum. Serum alkaline phosphatase (ALP) activity was determined by the method of Kind and King (1954). Serum progesterone concentration was estimated by using commercial ELISA kit (Omega diagnostics, pathozyme, progesterone, Scotland, UK).

\section{Immune response}

For assaying the immune response, the rats were challenged twice with sheep RBC $(0.5 \mathrm{x}$ $10^{9}$ cells/100 g, I/P), as an antigen and second challenge was given 7 days after first challenge. The blood was withdrawn from retroorbital plexus from all antigenically challenged rats after one week of primary and secondary challenge and HA titers were estimated as per method given by (1942). 25 $\mu l$ of serum was serially diluted with $25 \mu$ of phosphate-buffered saline (PBS). Sheep RBC $\left(0.025 \times 10^{9}\right.$ cells $)$ were added to each of these dilutions and incubated at $37^{\circ} \mathrm{C}$ for one hour. The rank of minimum dilution that exhibited hemagglutination was considered as the antibody titer. The CMI was assayed by footpad reaction method in all rats. The increase in the paw volume induced by an injection of sheep RBC $\left(0.025 \times 10^{9}\right.$ cells $)$, in the subplantar region of right hind paw, was assessed after $48 \mathrm{~h}$. The mean percent increase in paw volume was considered as DTH reaction and represented as an index of CMI. The volume of the left hind paw, injected similarly with PBS served as control

\section{Antioxidant enzyme activity in haemolysate}

The blood was collected from all rats on $83^{\text {rd }} \mathrm{d}$ in clean heparinized vacutainers, was centrifuged at $2000 \mathrm{rpm}$ for 15 minutes at $4^{\circ} \mathrm{C}$ to separate buffy coat and erythrocyte pellet. The erythrocytes were washed thrice with phosphate buffer saline (PH 7.4). The packed RBC obtained was mixed with an equal volume of phosphate buffer saline and then diluted as per requirement with distilled water. The antioxidant enzymes viz., RBC catalase, glutathione peroxidase (GPx) and glutathione reductase (GSH-Rx) in haemolysate were estimated as per the procedures of Bergmeyer (1983), Paglia and Valantine (1967) and Horn and Burns (1978), respectively and the enzyme activity was expressed as units per $\mathrm{g} \mathrm{Hb}, \mu \mathrm{M} / \mathrm{mg}$ protein and $\mu \mathrm{M} / \mathrm{mg}$ protein, respectively. The $\mathrm{Hb}$ and protein concentration in haemolysate was estimated colorimetrically as per the procedure described by Cannan (1958) and Lowry et al., (1951).

\section{Oxidative stress markers in liver}

After 12 weeks of experiment, all rats were sacrificed. Immediately after slaughter, liver was removed and perfused with normal saline $(0.9 \%)$ to reduce red blood cell contamination. The samples were then fixed in liquid nitrogen and stored at $-20^{\circ} \mathrm{C}$ for 
analysis. The estimation of oxidative stress markers i.e., thiobarbituric acid reacting substances (TBARS) and protein carbonyls were estimated as per the procedures of Balasubramanian et al., (1988) and Levine et al., (1990) respectively and was expressed as nmole per $\mathrm{mg}$ protein and nmole per $\mathrm{mg}$ protein, respectively. The reduced glutathione (GSH) was estimated by method described by Moron et al., (1979).

\section{Ovarian histology}

At end of experiment all rats were sacrificed and ovaries were collected and fixed in buffered formalin. The fixed tissues were embedded in paraffin $\left(58.6^{\circ} \mathrm{C}\right)$ to make paraffin blocks and were cut by a rotator microtome $(5 \mu)$. The sections were stained by eosine and haematoxylin and examined under a compound microscope. During microscopic examination, diameters and morphologies of the follicles were used to classify the follicles. The quantification study of folliculogenesis was performed according to Patil et al., (1988).

\section{Statistical analysis}

The results obtained were statistically analyzed by using one way ANOVA according to the method of Snedecor and Cochran (1980). The means were compared by Duncan's multiple range test (1955).

\section{Results and Discussion}

\section{Effect of zinc on body weight and feed intake}

No significant effect on weekly body weight changes was observed in rats fed $\mathrm{Zn}$ from various organic sources compared to $\mathrm{Zn}$ carbonate (inorganic source) throughout the feeding trial o (Table 2). Similarly, throughout the experiment the average daily feed intake (FI) in rats was statistically comparable among the dietary treatments, except on $4^{\text {th }}$ and $12^{\text {th }}$ weeks in which ZnAA and $\mathrm{Zn}$ prop supplemented rats showed lower $(\mathrm{P}<0.05)$ FI compared to control group (Table $3)$. Our results are in agreement with the findings of several researchers (Sridhar $e t$ al., 2014; Nagalakshmi et al., 2015a; 2016a,b) who observed no significant effect of source level of $\mathrm{Zn}$ supplementation on growth and feed intake of animals.

\section{Haematological and serum biochemical constituents}

Serum biochemical constituents in the present study were not affected by source of zinc in the diet (Table 4). The serum concentration of glucose, cholesterol, total protein, albumin, globulin and alkaline phosphatase activity was comparable between organic and inorganic sources. In corroborating with our findings, earlier researchers indicated no change in serum biochemical parameters in guinea pigs (Shinde et al., 2006) and rats (Nagalaskhmi et al., 2015a) fed diets were supplemented with organic Zn.

Similarly, haematological constituents analyzedin preset study was also not affected by source of zinc in diet (Table 5). All the parameters were comparable among various groups and were within the normal physiological limits (Hrapkiewicz and Medina, 2007). Scanty data available to compare these parameters, however in our previous studies, observed no significant difference in broiler chicken hematological parameters though reduced $\mathrm{Zn}$ supplementation by $25 \%$ of requirement using Zn glycinate (Sridhar et al., 2015b). Similarly Nagalakshmi et al., (2015a) observed no significant difference in $\mathrm{RBC}, \mathrm{Hb}$ concentration, haematocrit, $\mathrm{MCV}, \mathrm{MCH}$, lymphocyte, monocyte and granulocyte values among rats supplemented with $12 \mathrm{ppm}$ $\mathrm{Zn}$ either from organic or inorganic source. 
Oxidative stress markers and antioxidant enzyme activity

The RBC catalase activity was higher $(\mathrm{P}<0.01)$ with $\mathrm{Zn}$ methionine compared to $\mathrm{ZnCO}_{3}$ and other organic sources supplementation. The glutathione reductase activity was higher $(\mathrm{P}<0.05)$ with supplementation of $\mathrm{Zn}$ from organic source (except $\mathrm{Zn}$ propionate) compared to inorganic source (Table 6). Similarly, the reduced glutathione concentration in liver was higher $(\mathrm{P}<0.05)$ in rats fed organic sources of $\mathrm{Zn}$ compared to inorganic $\mathrm{Zn}$. However, the TBARS and protein carbonyls concentration in liver were comparable between inorganic and various organic sources (Table 6). Overall trend of antioxidant parameters in current experiment, indicating that the supplementation of $\mathrm{Zn}$ from organic source improved the antioxidant status of rats, though they were reared in environmentally controlled conditions (environmental stress free condition). Moreover better antioxidant status was observed with $\mathrm{Zn}$-methionine supplementation compared to other $\mathrm{Zn}$ sources. Similarly, Nagalakshmi et al., (2015a \&2016a) observed better antioxidant activity in rats supplemented with $\mathrm{Zn}$ methionine compared to $\mathrm{Zn}$ carbonate. Furthermore, Sridhar et al., (2016) observed improved antioxidant status of broiler chicken though reducing the $\mathrm{Zn}$ supplementation using organic $\mathrm{Zn}$ (Zn glycinate).

\section{Immune response}

The relationship between dietary $\mathrm{Zn}$ and the immune response has received much attention. The results of this study indicated this relationship is a crucial even among $\mathrm{Zn}$ sources. Zinc is an essential cofactor for thymulin, a thymic hormone that promote improved immune response through maturation of T-Cells and activation B-Cells by T-helper cells (Fraker et al., 1986). As noted in table 7 the primary immune response was not affected by source of $\mathrm{Zn}$ in the diet. While the secondary immune response was higher $(\mathrm{P}<0.05)$ when fed organic sources of zinc compared to inorganic source. However, no difference in antibody titers was observed among various organic sources of $\mathrm{Zn}$ tested. Similarly $\mathrm{Zn}$ sources had no much effect on primary immune response against sheep RBC, while secondary response found to be stronger in broiler birds fed on ZnMet containing diets (Moghaddam and Jahanian, 2009). Further, several earlier reports indicated improved humoral immune response with ZnMet (Moghaddam and Jahanian, 2009), ZnAA (Hudson et al., 2004), $\mathrm{Zn}$ propionate (Nagalakshmi et al., 2016b) and $\mathrm{Zn}$ proteinate (Mandal et al., 2011) supplementation. Although there is conflicting data regarding relative bioavailability among organic versus inorganic $\mathrm{Zn}$ sources, the present study indicated organic sources supplemented had considerable relative efficacy in promoting immune response. The CMI response expressed as skin delayed type hypersensitivity (DTH) reaction was higher $(\mathrm{P}<0.05)$ in rats fed $\mathrm{Zn}$ propionate as $\mathrm{Zn}$ source (Table 7). While, no effect of feeding other $\mathrm{Zn}$ sources was observed on CMI and it was comparable to inorganic source. Similarly, Nagalakshmi et al., (2016b) reported improved DTH response against PHA-P in buffalo heifers fed diets containing $\mathrm{Zn}$ propionate even at lower concentration (75\% of inorganic).

\section{Ovarian folliculogenesis and progesterone concentration}

Zinc has important role in female reproduction by influencing estrous cycle, gonadotropic hormones and ovarian folliculogenesis (Nagalakshmi et al., 2013b). Zinc has beneficial role in improving follicular number and regulate the survival 
and maturation of follicles at any stage of their development (Nagalakshmi et al., 2013b). The serum progesterone concentration in the present study was higher $(\mathrm{P}<0.05)$ in rats fed organic source of zinc compared to inorganic zinc and it was comparable among rats fed on various organic sources of zinc (Fig. 1). The data on ovarian folliculogenesis in the present study indicated that organic $\mathrm{Zn}$ had no effect on primary, secondary and tertiary follicle number while, graafian follicles and corpus luteum numbers were higher $(\mathrm{P}<0.05)$ in rats fed organic sources of zinc compared to inorganic source (Table 8).

Table.1 Ingredient composition of purified diet (AIN-76A)

\begin{tabular}{lc}
\hline Ingredient & Proportion, $\mathrm{g} / \mathrm{kg}$ diet \\
\hline Sucrose & 500.0 \\
Casein & 200.0 \\
Corn starch & 150.0 \\
Oil & 50.0 \\
Cellulose & 50.0 \\
Mineral mixture* & 35.0 \\
Vitamin mixture* & 10.0 \\
DL-methionine & 3.0 \\
Choline chloride & 2.0 \\
\hline and vitamin mixture was prepared as per specifications for AIN-76A
\end{tabular}

*Mineral and vitamin mixture was prepared as per specifications for AIN-76A

Table.2 Body weight changes $(\mathrm{g})$ in rats fed various organic sources of zinc

\begin{tabular}{|c|c|c|c|c|c|c|c|}
\hline \multirow[t]{2}{*}{ Week } & \multicolumn{5}{|c|}{ Zn source } & \multirow[t]{2}{*}{ SEM } & \multirow[t]{2}{*}{$P$ value } \\
\hline & $\mathrm{Zn}$ met & $\mathrm{Zn}$ aa & Zn prot & Zn prop & $\mathrm{ZnCO}_{3}$ & & \\
\hline Start & 275.0 & 275.1 & 275.0 & 275.0 & 275.0 & 2.039 & 0.999 \\
\hline 1 & 276.7 & 275.7 & 277.4 & 275.6 & 275.5 & 2.132 & 0.998 \\
\hline 2 & 277.8 & 276.5 & 278.4 & 275.9 & 275.7 & 2.019 & 0.993 \\
\hline 3 & 277.6 & 277.8 & 281.5 & 276.3 & 275.9 & 2.030 & 0.921 \\
\hline 4 & 280.6 & 279.2 & 281.9 & 277.2 & 276.0 & 1.956 & 0.883 \\
\hline 5 & 282.2 & 282.3 & 282.9 & 277.7 & 276.1 & 1.840 & 0.700 \\
\hline 6 & 282.3 & 282.4 & 283.7 & 278.6 & 277.6 & 1.867 & 0.822 \\
\hline 7 & 283.9 & 284.6 & 286.5 & 280.1 & 279.0 & 1.986 & 0.741 \\
\hline 8 & 270.4 & 271.8 & 269.4 & 268.5 & 269.7 & 2.260 & 0.994 \\
\hline 9 & 269.9 & 265.4 & 264.2 & 262.9 & 265.8 & 2.406 & 0.992 \\
\hline 10 & 274.6 & 269.9 & 273.4 & 263.2 & 266.7 & 2.244 & 0.532 \\
\hline 11 & 279.8 & 274.1 & 284.6 & 271.5 & 276.0 & 2.228 & 0.384 \\
\hline 12 & 288.3 & 280.8 & 287.8 & 281.3 & 281.4 & 2.317 & 0.725 \\
\hline
\end{tabular}

SEM: Standard errors of mean.

Zn met: Zn methionine; Zn aa: Zn amino acid complex; Zn prot: Zn proteinate; Zn prop: Zn propionate 
Int.J.Curr.Microbiol.App.Sci (2017) 6(2): 922-932

Table.3 Daily feed intake (g) in rats fed various organic sources of zinc

\begin{tabular}{llllllll}
\hline Week & \multicolumn{5}{c}{ Zn source } & SEM & P value \\
\cline { 2 - 6 } & Zn met & Zn aa & Zn prot & Zn prop & ZnCO $_{3}$ & & \\
\hline 1 & 15.12 & 13.70 & 14.93 & 15.11 & 16.92 & 0.411 & 0.179 \\
2 & 16.58 & 15.15 & 17.83 & 16.84 & 18.05 & 0.497 & 0.381 \\
3 & 14.81 & 13.60 & 14.39 & 13.64 & 15.91 & 0.400 & 0.351 \\
4 & $17.21^{\text {ab }}$ & $14.57^{\mathrm{b}}$ & $15.38^{\mathrm{ab}}$ & $14.65^{\mathrm{b}}$ & $17.96^{\mathrm{a}}$ & 0.456 & 0.043 \\
5 & 15.30 & 15.67 & 14.58 & 17.23 & 16.62 & 0.318 & 0.054 \\
6 & 16.06 & 16.32 & 17.36 & 16.02 & 17.06 & 0.325 & 0.616 \\
7 & 14.81 & 14.67 & 14.02 & 13.49 & 15.65 & 0.399 & 0.519 \\
8 & 12.60 & 11.87 & 12.08 & 11.44 & 13.89 & 0.286 & 0.054 \\
9 & 13.40 & 11.69 & 12.33 & 11.44 & 11.62 & 0.307 & 0.244 \\
10 & 14.08 & 15.33 & 15.49 & 14.94 & 15.02 & 0.382 & 0.826 \\
11 & 17.73 & 15.49 & 16.90 & 16.45 & 18.17 & 0.361 & 0.136 \\
12 & $18.89^{\mathrm{ab}}$ & $17.14^{\mathrm{bc}}$ & $19.92^{\mathrm{a}}$ & $16.13^{\mathrm{c}}$ & $18.81^{\mathrm{ab}}$ & 0.436 & 0.032 \\
\hline
\end{tabular}

${ }^{a b}$ Means with different superscripts in a row differ significantly: $\mathrm{P}<0.05$; SEM: Standard errors of mean. Zn met: Zn methionine; Zn aa: Zn amino acid complex; Zn prot: Zn proteinate; Zn prop: Zn propionate.

Table.4 Biochemical constituents in rats fed various organic sources of zinc

\begin{tabular}{llllllll}
\hline Attribute & \multicolumn{4}{c}{ Zn source } & SEM & P value \\
\cline { 2 - 6 } & Zn met & Zn aa & Zn prot & Zn prop & $\mathrm{ZnCO}_{3}$ & & \\
Glucose, mg/dl & 152.9 & 149.0 & 149.8 & 140.2 & 164.9 & 7.257 & 0.893 \\
Cholesterol, mg/dl & 117.6 & 130.0 & 144.6 & 119.0 & 128.9 & 5.309 & 0.530 \\
Alkaline phosphatase, IU/L & 475.0 & 465.8 & 468.1 & 488.7 & 462.9 & 25.19 & 0.998 \\
Total protein, g/dl & 9.47 & 10.68 & 9.34 & 11.38 & 9.20 & 0.535 & 0.656 \\
Albumin, g/dl & 3.12 & 3.12 & 3.38 & 3.02 & 3.23 & 0.081 & 0.706 \\
Globulin, g/dl & 6.35 & 7.56 & 5.96 & 8.36 & 5.97 & 0.571 & 0.616 \\
Albumin globulin ratio & 0.518 & 0.497 & 0.664 & 0.494 & 0.664 & 0.0542 & 0.739 \\
\hline
\end{tabular}

SEM: Standard errors of mean.

Zn met: Zn methionine; Zn aa: Zn amino acid complex; Zn prot: Zn proteinate; Zn prop: Zn propionate.

Table.5 Haematological constituents in rats fed various organic sources of zinc

\begin{tabular}{|c|c|c|c|c|c|c|c|}
\hline \multirow[t]{2}{*}{ Attribute } & \multicolumn{5}{|c|}{ Zn source } & \multirow[t]{2}{*}{ SEM } & \multirow[t]{2}{*}{$P$ value } \\
\hline & Zn Met & $\mathrm{Zn}$ AA & $\mathrm{Zn}$ prot & Zn prop & $\mathrm{ZnCO}_{3}$ & & \\
\hline Haemoglobulin (\%) & 17.42 & 16.76 & 17.66 & 17.08 & 17.96 & 0.193 & 0.320 \\
\hline $\mathrm{RBC}\left(\mathrm{x} 10^{6} / \mathrm{cumm}\right)$ & 10.66 & 10.65 & 11.18 & 10.68 & 11.40 & 0.156 & 0.420 \\
\hline WBC (x10\%3umm) & 5.20 & 6.79 & 6.63 & 5.82 & 6.13 & 0.282 & 0.403 \\
\hline HCT (\%) & 63.44 & 63.08 & 66.56 & 64.64 & 67.10 & 0.981 & 0.634 \\
\hline $\operatorname{MCV}(\%)$ & 59.40 & 59.6 & 59.0 & 60.40 & 58.40 & 0.349 & 0.538 \\
\hline $\mathrm{MCH}(\%)$ & 16.30 & 15.78 & 15.72 & 16.16 & 15.72 & 0.099 & 0.183 \\
\hline $\mathrm{MCHC}(\%)$ & 27.44 & 26.66 & 26.50 & 26.42 & 26.92 & 0.178 & 0.388 \\
\hline Lymphocytes (\%) & 52.60 & 50.36 & 54.92 & 56.20 & 50.64 & 2.962 & 0.969 \\
\hline Monocytes (\%) & 7.32 & 5.86 & 7.48 & 6.94 & 7.26 & 0.810 & 0.977 \\
\hline Granulocytes (\%) & 40.14 & 43.80 & 37.60 & 36.84 & 42.12 & 3.061 & 0.955 \\
\hline
\end{tabular}

SEM: Standard errors of mean.

Zn met: Zn methionine; Zn aa: Zn amino acid complex; Zn prot: Zn proteinate; Zn prop: Zn propionate. 
Table.6 Oxidative enzyme activities in haemolysate and liver of rats fed various organicsources of zinc

\begin{tabular}{|c|c|c|c|c|c|c|c|}
\hline \multirow{2}{*}{ Attribute } & \multicolumn{5}{|c|}{ Zn source } & \multirow{2}{*}{ SEM } & \multirow{2}{*}{$P$ value } \\
\hline & Zn Met & Zn AA & Zn prot & Zn prop & $\mathrm{ZnCO}_{3}$ & & \\
\hline Haemolysate & & & & & & & \\
\hline RBC Catalase (Umole/min/Hb) & $17.30^{\mathrm{a}}$ & $6.27^{\mathrm{b}}$ & $6.22^{\mathrm{b}}$ & $6.77^{\mathrm{b}}$ & $5.48^{\mathrm{b}}$ & 1.171 & 0.001 \\
\hline $\begin{array}{l}\text { Glutathione reductase ( } \mathrm{uM} / \mathrm{mg} \\
\text { protein) }\end{array}$ & $9.59^{\mathrm{ab}}$ & $12.34^{\mathrm{a}}$ & $12.33^{\mathrm{a}}$ & $4.83^{b}$ & $5.19^{b}$ & 1.094 & 0.044 \\
\hline \multicolumn{8}{|l|}{ Livers } \\
\hline TBARS (nM MDA/mg protein) & 0.026 & 0.027 & 0.024 & 0.024 & 0.029 & 0.0025 & 0.962 \\
\hline $\begin{array}{l}\text { Protein carbonyls (nM/mg } \\
\text { protein) }\end{array}$ & 1.18 & 1.13 & 1.03 & 1.13 & 1.07 & 0.211 & 0.475 \\
\hline $\begin{array}{l}\text { Reduced glutathione (uM/mg } \\
\text { protein) }\end{array}$ & $40.36^{\mathrm{b}}$ & $43.76^{\mathrm{b}}$ & $43.22^{\mathrm{b}}$ & $62.83^{\mathrm{a}}$ & $26.71^{\mathrm{c}}$ & 2.601 & 0.001 \\
\hline
\end{tabular}

${ }^{a b c}$ Means with different superscripts in a row differ significantly: $\mathrm{P}<0.01$; $\mathrm{P}<0.05$; SEM: Standard errors of mean. $\mathrm{Zn}$ met: Zn methionine; Zn aa: Zn amino acid complex; Zn prot: Zn proteinate; Zn prop: Zn propionate.

Table.7 Humoral and cell mediated immune response in rats fed various organic sources of zinc

\begin{tabular}{|c|c|c|c|c|c|c|c|}
\hline \multirow{2}{*}{ Attribute } & \multicolumn{5}{|c|}{ Zn source } & \multirow{2}{*}{ SEM } & \multirow{2}{*}{$\mathrm{P}$ value } \\
\hline & Zn Met & $\mathrm{Zn} \mathrm{AA}$ & Zn prot & Zn prop & $\mathrm{ZnCO}_{3}$ & & \\
\hline \multicolumn{8}{|l|}{ HA titres $\left(\log _{2}\right)$} \\
\hline Primary response & 5.00 & 5.17 & 4.83 & 5.00 & 5.00 & 0.179 & 0.989 \\
\hline Secondary response & $7.00^{\mathrm{a}}$ & $6.83^{\mathrm{a}}$ & $6.00^{\mathrm{ab}}$ & $6.67^{\mathrm{a}}$ & $5.50^{\mathrm{b}}$ & 0.170 & 0.015 \\
\hline \multicolumn{8}{|c|}{ Cell mediated immune response (\% increase in paw volume) } \\
\hline $48 \mathrm{~h}$ & $8.69^{\mathrm{b}}$ & $8.06^{\mathrm{b}}$ & $8.20^{\mathrm{b}}$ & $10.17^{\mathrm{a}}$ & $8.65^{\mathrm{b}}$ & 0.239 & 0.037 \\
\hline
\end{tabular}

${ }^{a b c}$ Means with different superscripts in a row differ significantly: $\mathrm{P}<0.01 ; \mathrm{P}<0.05$;SEM: Standard errors of mean.

$\mathrm{Zn}$ met: Zn methionine; Zn aa: Zn amino acid complex; Zn prot: Zn proteinate; Zn prop: Zn propionate.

Table.8 Number of different follicles (\%) in ovary of rats fed diets supplemented with various organic sources of zinc

\begin{tabular}{llllllll}
\hline \multirow{2}{*}{ Attribute } & \multicolumn{7}{c}{$\mathrm{Zn}$ source } \\
\cline { 2 - 6 } Primary follicles & 66.81 & 66.82 & 68.35 & 63.12 & 76.95 & 2.038 & 0.281 \\
Secondary follicles & 4.38 & 7.99 & 4.92 & 6.08 & 9.54 & 1.018 & 0.478 \\
Tertiary follicles & 3.75 & 3.55 & 2.62 & 1.47 & 1.61 & 0.516 & 0.513 \\
Graafian follicle & $8.85^{\mathrm{a}}$ & $8.36^{\mathrm{a}}$ & $7.96^{\mathrm{a}}$ & $7.46^{\mathrm{a}}$ & $2.47^{\mathrm{b}}$ & 0.762 & 0.047 \\
Corpus luteum & $16.22^{\mathrm{ab}}$ & $13.27^{\mathrm{b}}$ & $16.14^{\mathrm{ab}}$ & $21.13^{\mathrm{a}}$ & $9.43^{\mathrm{b}}$ & 1.679 & 0.021 \\
\hline
\end{tabular}

${ }^{a b}$ Means with different superscripts in a row differ significantly: $\mathrm{P}<0.05$; SEM: Standard errors of mean.

$\mathrm{Zn}$ met: Zn methionine; Zn aa: Zn amino acid complex; Zn prot: Zn proteinate; Zn prop: Zn propionate. 
Fig.1 Progesterone concentration $(\mathrm{ng} / \mathrm{ml})$ in serum of rats fed diets supplemented with various organic sources of zinc

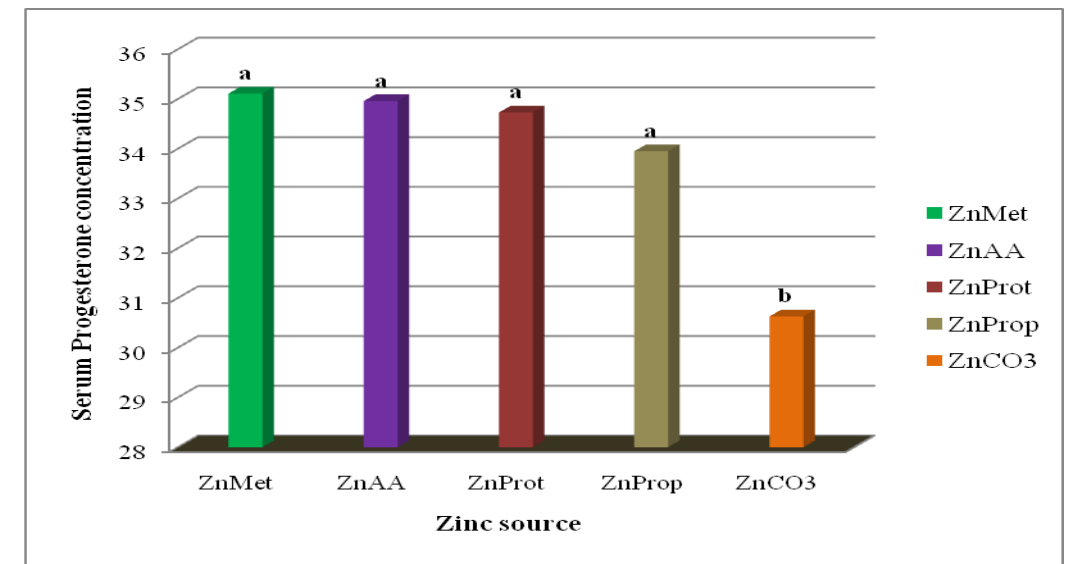

${ }^{a b}$ Bars with different superscripts differ significantly: $\mathrm{P}<0.05$

Zn Met: Zn methionine; Zn AA: Zn amino acid complex; Zn Prot: Zn Proteinate; Zn prop: Zn propionate.

Similarly, supplementation of $\mathrm{Zn}$ as $\mathrm{ZnO}$ in Baladi ewes at 100 and $150 \mathrm{ppm}$ increased the large follicles and ovulation rate subsequently improved the reproductive performance by decreasing the numbers of days to oestrus, increasing the incidence of oestrus, pregnancy, lambing rates compared to $50 \mathrm{ppm}$ supplemented ewes (Monem and El-Shahat, 2011). Further, earlier reports on chelated $\mathrm{Zn}$ supplementation in heifers exhibited higher number of mature follicles and corpus lutea (Manspeaker et al., 1987). Thus it indicated that higher concentration or more bioavailable organic $\mathrm{Zn}$ sources had beneficial effect on maturation of preantral (primary, secondary and tertiary) follicles into subsequent stages such as antral (graafian) follicles followed by ovulation to form corpus lutea. Furthermore, Nagalakshmi et al., (2015b) reported that $\mathrm{Zn}$ concentration in diets could be reduced by $75 \%$ when supplemented as $\mathrm{Zn}$ nicotinate (organic $\mathrm{Zn}$ ) without affecting the oestrus cycle and follicular population. In addition they observed increased follicular population in rats with $100 \%$ substitution of inorganic $\mathrm{Zn}$ with organic $\mathrm{Zn}$.

In conclusion, the present study indicated that rats fed diets containing various organic sources of $\mathrm{Zn}$ had higher antioxidant enzyme activities, immune response and serum progesterone concentration with higher number of mature follicles in ovaries compared to inorganic. Though no differences among various organic $\mathrm{Zn}$ sources was observed on these attributes, the cell mediated immunity and number of follicles converting to corpus luteum in ovaries was comparatively higher with $\mathrm{Zn}$ propionate.

\section{Competing interests}

The authors declare that they have no competing interests.

\section{References}

Balasubramanian, K.A., Manohar, M. and Mathan, V.I. 1988. An unidentified inhibitor of lipid peroxidation in intestinal mucosa. Biochimicaet. Biophysica Acta, 962: 51-58.

Bergmeyer, H.U. 1983. Methods of enzymatic analysis. In: Catalase (Weinheim, VerlagChemie), 2: 165-166.

Cannan, R.K. 1958. Laboratory Methods, Proposal for a certified standard for use in hemoglobinometry second and final report. J. Lab. Clin. Med., 52(3): 471-476. 
Cooper, G. R. and Mc Daniel, V. 1970. Assay methods. In: Mc Donald R.P. (Ed.) Standard methods for clinical chemistry. John Wiley and Sons, New York. 159-170.

Duncan, D.B. 1955. Multiple 'F' test. Biometrics, 1: 142 .

Fraker, P.J., Gershwin, M.E., Good, R.A. and Prasad, A.S. 1986. Interrelationships between zinc and immune function. FASEB. J., 45: 1474-1479.

Gustafson, E.J. 1976. Improved specificity of serum albumin determination and estimation of acute phase of reactants by use of the bromocresol green. Clin. Chem., 22: 616-622.

Hafeez, B., Khanif, Y. M. and Saleem, M. 2013. Role of zinc in plant nutrition-a review. American J. Experimental Agri., 3(2): 374.

Hirst, G.K. 1942. The quantitative determination of influenza virus and antibodies by means of red cell agglutination. J. Exper. Med., 75: 49-64.

Horn, H.D. and Burns, F.H. 1978. Methods of Enzymatic Analysis. In: Bergmeyer H V, editor. Academic Press, New York, p. 875.

Hrapkiewicz, K. and Medina, L. 2007. Clinical laboratory animal medicine - an introduction. $3^{\text {rd }} \mathrm{Ed}$. Blackwell publishers, USA.

Hudson, B.P., Dozier, W.A., Wilson, J.L., Sander, J.E. and Ward, T.L. 2004. Reproductive performance and immune status of caged broiler breeder hens provided diets supplemented with either inorganic or organic sources of zinc from hatching to 65 wk of age. J. Appl. Poult. Res., 13: 349359.

Kind, P.R. and King, E.J. 1954. Estimation of plasma phosphatase by determination of hydrolyzed phenol with amino-antipyrine.

J. Clin. Path., 7: 322-326.

Levine, R.L., Garland, D., Oliver, C.N., Amici, A., Climent, I., Lenz, A.G., Ahn, B.W., Shaltiel, S. and Stadtman, E.R. 1990. Determination of carbonyl content in oxdatively modified proteins. Methods in Enzymol., 186: 464-478.

Lowry, O.H., Rosenberg, N.J., Farr, A.L. and Randal, R.J. 1951. Protein measurement with the Folin-Phenol reagent. J. Biol.
Chem., 193: 265-275.

Mandal, G.P., Roy Amitava., Samanta, I. and Biswas, P. 2011. Influence of dietary zinc and its sources on growth, body zinc deposition and immunity in broiler chicks. Indian J. Anim. Nutr., 28(4): 432- 436.

Manspeaker, J.E., Robl, M., Edwards, G.H. and Douglass, W.G. 1987. Chelated minerals: their role in bovine fertility. Vet. Med., 82: 951-956.

Moghaddam, H.N. and Jahanian, R. 2009. Immunological responses of broiler chicks can be modulated by dietary supplementation of zinc-methionine in place of inorganic zinc sources. Asian-Aust. J. Anim. Sci., 22(3): 396-403.

Monem, A.U.M. and El-Shahat, K.H. 2011.Effect of different dietary levels of inorganic zinc oxide on ovarian activities, reproductive performance of Egyptian Baladi ewes and growth of their lambs. Bulg. J. Vet. Med., 14(2): 116-123.

Moron, M.J., Diperre, J.W., Mannerv, K.B. 1979.Levels of glutathione, Glutathione reductase and Glutathione-s-transferase activities in rat lungs and liver. Biochimicaet Biophysica Acta., 582: 67-71.

Nagalakshmi, D., Dhanalakshmi, K. and Himabindu, D. 2009.Effect of dose and source of supplemental zinc on immune response and oxidative enzymes in lambs. Vet. Res. Commun., 33(7): 631-644.

Nagalakshmi, D., ParashuRamulu, S. and Usha Rani, M. 2012.Effect of graded levels of zinc supplementation on growth performance and oxidative defense mechanism in rats. IOSR J. Pharm., 2(6): 36-41.

Nagalakshmi, D., Parashuramulu, S., Usha Rani, M., Kalakumar, B., Shivakumar, P. and Reddy A Gopala. 2013a. Effect of zinc supplementation on immune response, haematological and serum biochemical constituents in rats. Inventi Rapid: Biomed. Analysis, 1: 1-4.

Nagalakshmi, D., SadasivaRao, K., Aruna, G. and Parashuramulu, S. 2013b. Influence of dietary zinc supplementation on ovarian folliculogenesis in rats. Int. J. Recent Scientific Res., 4(4): 1-3.

Nagalakshmi, D., Sridhar, K. andParashuramulu, 
S. 2015a. Replacement of inorganic zinc with lower levels of organic zinc (zinc nicotinate) on performance, hematological and serum biochemical constituents, antioxidants status, and immune responses in rats. Vet. World, 8(9): 1156-1162.

Nagalakshmi, D., Rao, K.S., Aruna, G. and Sridhar, K. 2015b. Effect of Replacing Inorganic Zinc with Lower Levels of Organic Zinc on Zinc Retention and Follicular Population in Rats. J. Anim. Res., 5(4): 743-748.

Nagalakshmi, D., Sridhar, K., Swain, P. S. and Reddy, A. G. 2016a. Effect of substituting increasing levels of organic $\mathrm{Zn}$ for inorganic $\mathrm{Zn}$ on performance, hematological and serum biochemical constituents, antioxidant status and immune response in rat. Iranian J. Vet. Res., 17(2): 111-117.

Nagalakshmi, D., Rao, K. S., Kumari, G. A., Sridhar, K., \&Satyanarayana, M. 2016 b. Comparative evaluation of organic zinc supplementation as proteinate with inorganic zinc in buffalo heifers on health and immunity. The Indian J. Anim. Sci., 86(3): 322-328.

NRC. 1995. Nutrient requirements of laboratory animals. $4^{\text {th }}$ revised edition, National Academy of Science, Washington, DC.

Nitrayova, S., Windisch, E., Von Heimendahl, A., Müller.andBartelt, J. 2012.Bioavailability of zinc from different sources in pigs. $J$. Anim. Sci., 90: 185-187.

Paglia, D.E. and Valentine, W.N. 1967.Studies on the quantitative and qualitative of erythrocyte glutathion peroxidase. J. Lab. Clin. Med., 70: 158-168.

Patil, S.R., Ravindra Patil, S.R., Londonkar, R. and Patil, S.B. 1988. Nicotine induced ovarian and uterine changes in albino mice.
Indian J. Physiol. Pharamacol., 42: 503508.

Reinhold, J.G. 1953. Standard methods of clinical chemistry C, (Ed.) Rynner, M, New York, Academic Press.p. 88.

Shinde, P., Dass, R.S., Garg, A.K., Chaturvedi, V.K. and Kumar, R. 2006.Effect of zinc supplementation from different sources on growth, nutrient digestibility, blood metabolic profile and immune response of male guinea pigs. Biol. Trace Elem. Res., 112(3): 247-262.

Snedecor, G. W. and Conchran, W. G. 1980.Statistical method $7^{\text {th }}$ Ed. Iowa State Univ Press. Ames. Iowa, USA.

Sridhar, K., Nagalakshmi, D., Rao, D. S. andRao, S. V. 2014. Effect of dietary addition of organic zinc on performance and carcass traits in commercial broiler chicken. Indian J. Poult. Sci., 49(2): 155-158.

Sridhar, K., Nagalakshmi, D., SrinivasaRao, D. and Rama Rao, S.V. 2015a. Effect of supplementation of graded levels of organic zinc on nutrient utilization and retention of minerals in broiler chicken. Indian J. Anim. Nutr., 32(1): 80-85.

Sridhar, K., Nagalakshmi, D and Rama Rao, S.V. 2015b. Effect of graded concentration of organic zinc (Zn-glycinate) on skin quality, haematological and serum biochemical constituents in broiler chicks. Indian $J$. Anim. Sci., 85(6): 643-648.

Sridhar, K., Nagalakshmi, D., SrinivasaRao, D. and Rama Rao, S.V. 2016.Effect of graded concentration of organic zinc (zinc glycinate) on antioxidants status and immune response in commercial broilers. Indian J. Anim. Res., 50(4): 471-475

Wybenga, D.R. and Pileggi, V.J. 1970.Estimation of cholesterol. Clin. Chem., 16: 980-981.

\section{How to cite this article:}

Nagalakshmi, D., K. Sadasiva Rao, G. Aruna Kumari, S. Parashuramulu and Sridhar, K. 2017. Replacement of Inorganic Zinc with Various Organic Zinc Sources on Haematological Constituents, Antioxidant Status, Immune Response and Reproductive Efficiency in Rats. Int.J.Curr.Microbiol.App.Sci. 6(2): 922-932. doi: http://dx.doi.org/10.20546/ijcmas.2017.602.103 